\title{
'I'VE CHANGED' SAYS SOUTH AFRICAN LAW: HAS THE JUDICIARY OPENED UP TO BLACK WOMEN LAWYERS?
}

by Cebolenkosi Makhaye*

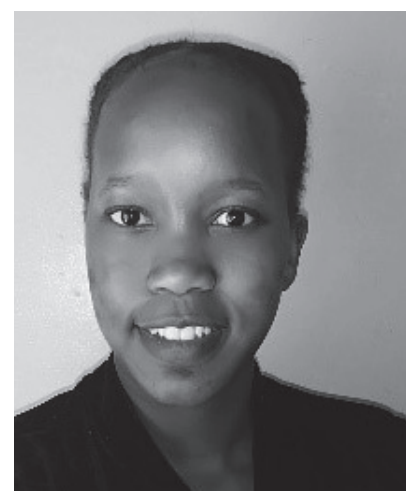

\section{Introduction}

Historically, South African law and legal culture has been an exclusionary field towards a number of different groups of people. One of the most glaring of these exclusions is that of black women lawyers. South African law and politics have claimed to have changed, but one still finds spaces that have not quite had the substantial kind of change that would be in line with the transformative nature that our constitution demands or at the very least, there is still plenty of room for improvement.

The 2017/2018 statistics from the Law Society of South Africa (LSSA) ${ }^{1}$ paints a clear picture of the past and current legal spheres. I will also rely on some sentiments that I have read from a number of black women scholars in legal practice to give the perspective to what working as a black women lawyer in South Africa is like.

* $\quad$ BA (Law), LLB Third Year Student (University of Pretoria). ORCID: 0000-0001-89475739. I would like to thank Ms Lizelle le Roux for her critical engagement, advice and feedback while I was completing this article. I would also like to thank my Editor, Phenyo Sekati as well as the Editor-in-Chief, Simon Motshweni for their outstanding contribution in getting this article ready for publication.

1 Law Society of South Africa 'LEAD Statistics on the profession' July 2018 http: / / www.lssa.org.za (accessed 09 May 2019). 
Professional spaces in South Africa have been found to be more favourable towards white people when compared to black and mixed race people. This was one of the main findings in a study on multiculturalism in the workplace from 2017 to 2018. ${ }^{2}$ This would mean that in order to 'fit in' with that kind of professional environment, black and mixed race people would need to assimilate and act similarly to the dominant 'other' thereby sacrificing their own voice. South Africa has a very long history of exclusion and the effects of that history do not just disappear.

There still seems to be a void within the legal field when it comes to transformation. It would also be safe to say that even if the profession was to fully embrace the process of transformation and specifically, transformative constitutionalism, it would still need to take into account the fact that transformation is a never ending journey, it is not fixed, but rather evolves with the needs and dynamics of the people.

Karl Klare coined the term 'transformative constitutionalism'.3 Langa CJ has said that the term has no single definition because the word brings about features of changeability. ${ }^{4}$ Klare has defined transformation as a social and economic revolution, a means to provide greater access through actions such as affirmative actions. ${ }^{5}$ Klare also states that transformative constitutionalism is committed to substantive equality, which entails getting rid of not only changing society in theory, but also substituting the overtly racist, overtly sexist and other overtly discriminatory laws and practices with those that are inclusive. Substantive equality, in the process of transformative constitutionalism, also involves the complete removal of the structures which were used to create an unequal society, as well as the redistribution of resources and power in accordance to the values of freedom, human dignity and equality. ${ }^{6}$

\section{Demographics in the legal industry of South Africa}

The Law Society of South Africa is a leading source for developments within the attorney's profession in the country. Recent statistics for

2 LT Jackson \& FJ van de Vijver 'Multiculturalism in the workplace: Model and test' (2018) 16 SA Journal of Human Resource Management 76.

3 K Klare 'Legal Culture and Transformative Constitutionalism' (1998) 14 South African Human Rights Journal 146.

4 P Langa 'Transformative constitutionalism' (2006) 17 Stellenbosch Law Review 351 .

$5 \quad$ Klare (n 3 above) 352.

6 C Albertyn \& B Goldblatt 'Facing the challenge of transformation: Difficulties in the development of an indigenous jurisprudence of equality' (1998) 14 South African Journal on Human Rights 248-249. 
the profession range from the number of registered LLB/BA Law/ BCom Law students up until the number of admitted attorneys and magistrates. Overall, the more recent numbers (2018 statistics) ${ }^{7}$ show an increase in the number of black women entering the field as attorneys. As far as university statistics are concerned, there is a substantial number of final LLB graduates in 2018. This shows that there is no shortage in black women lawyers who want to become lawyers (or who at the very least show an interest in studying the (aw). Thus, it would be insufficient to argue that a lack in substantive transformation in the legal sphere is due to black people or black women not wanting to be in the industry or being uninterested in it.

Although more women graduate from law school, the problem arises when it comes to actually entering into the profession, as it is the men who are more present in that regard. ${ }^{8}$ Practising women advocates are reported to sit at a measly $24 \%$ of all practising advocates with $64 \%$ of them being white female advocates, $4 \%$ representing black women. Indian women make up 2,8\% and Coloured women make up $1,6 \%$. The remaining $27,6 \%$ did not specify race. It is not my intention to overload this paper with percentages, however they can help in painting a fuller picture of how women of various races fit into the legal profession and whether there is space for them as professionals in which they can substantively add to the profession and hopefully thrive as lawyers in South Africa.

For attorneys, there is a general trend that is closer in reflecting the gender composition of the country. When referring to LLB registrations, graduation rates, articles and attendance at law schools, the presence of women is on the rise each time and the numbers are usually consistently higher for women than for men. This is measuring the trends from 2010 until 2017. There is a switch when it comes to admission of women and the numbers of women practising as attorneys. In 2017, women only made up 39\% of practising attorneys and a linear prediction shows that it would probably take another 35 years for the number of male and female practising attorneys to become equal. ${ }^{10}$ It would be reasonable to infer that the bulk of women lawyers in the country are white women, given that white people outnumber all races when looking at the profession (this is not inclusive of university admissions and graduation rates). The most saturated law society, the Society of the Northern Provinces has shown an increase in the number of black

7 Law Society of South Africa 'LEAD Statistics on the profession' July 2018 http:// www.lssa.org.za (accessed 09 May 2019).

8 C Albertyn \& E Bonthuys 'South Africa: A transformative constitution and a representative judiciary' in G Bauer \& J Dawuni (eds) Gender and the judiciary in Africa: From obscurity to parity (2006) 58.

9 T Meyer 'Female Attorneys in South Africa: A Quantitative Analysis' (2018) 42 African Journal of Employee Relations 7-10.

10 Meyer (n 9 above) 10-11. 
attorneys over the $2007-2017$ period, ${ }^{11}$ which is encouraging especially when one thinks of how Gauteng was one of the strongholds of the apartheid government. However, it is white attorneys which have been dominant in this society. ${ }^{12}$ It was observed in the statistics that senior positions in the legal profession from the law firms, the Bar and the judiciary still have one particular category of people who are dominating: white men. ${ }^{13}$

\section{Challenges faced by black (women) lawyers}

The CALS (Centre for Applied Legal Studies) has identified some of the challenges that black women lawyers face which include: a shortage of jobs; limited connections to established legal professionals; greater offers from the corporate sector than the legal sector; cultural alienation, bias, racism, sexual harassment, briefing patterns to the disadvantage of black women, reinforcing gender roles/ stereotypes and trailblazer standards which are enforced to the disadvantage of black women. ${ }^{14}$

In the study, the CALS found many instances which speak to the treatment of black women lawyers in the workplace and it was found that there are domestic stereotypes which play a role in the workplace. Participants in the study spoke on having to be conscious of not promoting preconceived ideas and attitudes that associated black lawyers with laziness, incompetence or figurehead employees used for BBBEE compliance. 15

Invisible rules governing social life outside work, such as weekend golf matches, was also mentioned as a barrier. Social interactions, especially the playing of golf, is known as a gateway to gaining work between lawyers. ${ }^{16}$ The general idea is that it is easier to learn how to play the sport than try to rebel, a classic example that is used by lawyers is the expectation that 'one cannot succeed if you do not go skiing with the right people'. The study furthermore found consistent evidence of sexual harassment, gender discrimination as well as discrimination based on race are factors which are haemorrhaging the transformation and advancement of the legal profession. ${ }^{17}$

The work that black women produce in an effort to access senior positions, is judged against a much higher standard while the same standard of excellence does not necessarily apply to white men. The

11 Law Society of South Africa (n 7 above).

12 Law Society of South Africa (n 7 above).

13 Law Society of South Africa (n 7 above).

14 Centre for Applied Legal Studies 'Transformation of the legal profession' 2014 10-12.

15 Centre for Applied Legal Studies (n 14 above) 44

16 Centre for Applied Legal Studies (n 14 above) 38.

17 Centre for Applied Legal Studies (n 14 above) 38. 
benefit of the doubt, or benefit of being viewed as capable and competent from the get-go is not available to black women in the way that it is for their white counterparts. ${ }^{18}$

Another prominent problem within the legal industry lies in the State's lack of support for black lawyers. The Black Lawyers' Association - an organisation that advocates for black lawyers in South Africa - had marched to Union Buildings in July of 2017 to speak out on the government's side-lining of black lawyers, advocating specifically for black women lawyers. ${ }^{19}$ The government has been characterised as the 'largest consumer of legal services and the main policy driver of transformation in the legal profession' because of its aims and duties towards redressing the injustices of the past. ${ }^{20}$ The onus is on the government to lead in making the necessary strides for black women lawyers within the profession. If not, the system of exclusion will continue even through the era of democracy.

Reports from the organisation and from some practicing black lawyers, have expressed how black lawyers experience being deliberately left out or overlooked in the legal field despite having the required skills and qualifications. ${ }^{21}$ This paints a contrasting picture to the demographics, or at least to the real experiences of black [women] lawyers in South Africa. An example is the infamous phenomenon of skewed briefing patterns in favour of one type of lawyer over others. ${ }^{22}$ This also goes against the overall goal of transformation that our democracy seeks to achieve. It is simply not enough to have a certain number of black lawyers present in the field and let that be the end of the transformation in law. There also needs to be substantive change. A study done by a UNISA senior lecturer and a LSSA independent consultant, Mr Tsili Phooko, revealed that of the sample which responded to the study, $50 \%$ of the black advocates that were briefed were male and only $17 \%$ were female. A similar pattern for Indian and Coloured lawyers was presented; a significantly much higher number of male advocates than female advocates. It was also revealed that at some private firms, it was not uncommon to have senior practitioners instruct which advocates get which brief. Although the research was not conclusive due to there being entities which did not submit their data in time for the study, it was concluded

18 Centre for Applied Legal Studies (n 15 above) 44.

19 A Mitchley, News24 'Stop feeding us crumbs, black lawyers tell government' 14 July 2017 https://www.news24.com/SouthAfrica/News/stop-feeding-uscrumbs-black-lawyers-association-tells-govt-20170714 (accessed 09 May 2019).

20 RM Phooko \& SB Radebe 'Twenty-three years of gender transformation in the Constitutional Court of South Africa: Progression or Regression' (2016) 8 Constitutional Court Review 322.

21 N Manyathi-Jele 'LSSA hosts summit on briefing patterns' 25 April 2016 http:// www.derebus.org.za/lssa-hosts-summit-briefing-patterns/ (accessed 29 May 2020).

22 Law Society of South Africa (LSSA) 'Summit on briefing patterns in the legal profession' (31 March 2016). 
that there is an 'unequal distribution of work'. ${ }^{23}$ A disturbing challenge that was revealed by the study was that some participants spoke of being overlooked if they were female with the exception being if the particular female was considered to be 'pretty'. Coupled with the stereotypes faced by black lawyers, such as being described as incompetent or being undermined because of which institution they had studied at, the results expose the many setbacks faced for a lawyer who is black and female. 24

Perhaps also, the fact that at the start of the country's democracy, the Constitutional Court only had two women permanently appointed - Justices Yvonne Mokgoro and Katherine O'Regan- might have set a certain tone or pattern for the low numbers of women in the profession. ${ }^{25}$ The judiciary has had great milestones in achieving racial diversity, growing from seven white Justices and four black Justices to the current bench of 7 'African' judges and 1 male 'Coloured' judge (in effect totalling 8 black judges). Justice Tshiqi and Justice Majiedt were only appointed in October 2019 by President Ramaphosa and Justice Cameron has recently retired. Prior to that, between 1994 and 2014, the number of women in the Constitutional Court remained at two, despite the upward pattern of the number of women graduating with law degrees from the early 2000s. The numbers in the lower courts (High Court, Labour Appeal, Land Claims court etc.) have been more encouraging in terms of appointing women judges. In 2012, 14 women out of 61 candidates were appointed as judges, 77 out of a total of 239 judges were women in 2013. ${ }^{26}$

The issue of attaining mentors for young lawyers is also a challenge to women lawyers and was raised at the Law Society of South Africa's Summit on Briefing Patterns. ${ }^{27}$ Mentorship is especially important when one looks at the societal and economic background that is most prevalent for black women across the country. Advocate Samantha Martin, who was one of the individuals on the 'legal' panel at the LSSA'S summit, spoke on challenges faced by advocates at the Johannesburg Bar Council and stated that there is a void in respect of mentors for young female advocates. Former Chairperson of the Bar Council, Adv Dali Mpofu SC, highlighted that despite $76 \%$ of briefs being allocated to previously disadvantaged persons, the number on its own was meaningless without looking at the quality of briefs being sent to these individuals. This is, yet again, a nod towards substantive change. It is all good and well to dish out briefs to black lawyers, women lawyers or black women lawyers in great numbers, but those

Law Society of South Africa (n 7 above).

LSSA (n 22 above), Manyathi-Jele (n 21 above).

Phooko (n 20 above) 318.

Centre for Applied Legal Studies (n 14 above) 7-8.

LSSA (n 22 above). 
briefs cannot be solely fewer complex briefs. Previously disadvantaged lawyers should get the opportunity, like any other practitioner, to explore their abilities to handle a range of legal cases and matters, to improve their skills and enhance their legal experience. According to Adv Mpofu, young female advocates join the bar but within a year or two, they leave 'because of no work'. From this, the necessity of mentors becomes even clearer, especially for young, black women practitioners.

The black middle class, despite no consensus over its exact size, is a much smaller class of people when compared to rest who are living in poverty with 'limited access to socio-economic services'. ${ }^{28}$ If one is not part of this small pool of the middle class nor the even smaller Black elite class, it is highly unlikely that black people can enter into the legal profession without deliberate positive reinforcement tools that will build their skills, education and assist them in accessing socio-economic services and rights which they have been guaranteed in the Constitution. ${ }^{29}$

\section{A brief look at the composition of the judiciary of South Africa in the democratic era}

As mentioned, the dawn of democracy saw only two women being appointed as Justices of the very first Constitutional Court. The number is not even half of the bench and thus does not reflect the nation's gender and race composition. ${ }^{30}$ At the dawn of democracy, women, and particularly black women lawyers were already lagging behind in terms of representation in the land's highest court. The composition of the original Constitutional Court set up a pattern for the rest of the judiciary because the appointment of judges in various courts have shown leaps and bounds in changing the racial composition in favour of African judges but again, it would seem that it would be male African judges that would be leading in this category. A look at the LSSA's 2012 statistics on the appointment of permanent judges reveals the how slowly the gender transformation has been in the country's judiciary. ${ }^{31}$

Judges represent the interests of black women lawyers in that women are likely to have a better understanding of issues affecting women, as argued by Budlender, especially in a society where women

28 Phooko (n 20 above) 321

29 Phooko (n 20 above) 321-322, The Constitution of the Republic of South Africa, 1996.

30 Phooko (n 20 above) 318.

31 LSSA LEAD 'Statistics on the profession March 2012' http://www.lssa.org.za (accessed 29 May 2020). 
make up just over $50 \%$ of the population. ${ }^{32}$ Black lawyers are also more likely (compared to white judges) able to relate and understand the life experiences and needs of the majority of South Africans. ${ }^{33}$ If these arguments were to be applied to a black women in law, it would reasonable to deduce that the appointment or increased representation of black women as judges would, in effect, make for the functioning of courts that are more in tune with the life experiences and needs of the public that it serves with a better understanding of issues affecting women - an all too important factor given the rise of gender-based violence in the country.

In a 2016 investigative report, the Commission for Gender Equality, revealed that the major South African corporate law firms are still dominated by white men and particularly the higher/ executive positions. ${ }^{34}$ This was done via a survey by the South African Legal Fellows Network in 2013. ${ }^{35}$ This is reminiscent of the pre-1994 version of the legal profession and it is discouraging to note the similarities 20 years after the beginning of a democracy.

\section{A look at the history of the composition of the South African legal profession}

Many legal scholars describe the law of South Africa as consisting of a Euro-Western jurisprudence. The name itself, is telling of the heavy influence of European thought and reasoning on European law and theories of law. Essentially, the norms, values and the overall culture of Europe/the West is what informs the foundation of its laws. The issue comes in where this kind of law, with the kind of foundation it has, is imposed on a people of a totally different culture and made to permeate as the only acceptable way for human beings to function in a society.

\section{The impact of the west on the law and legal education in South Africa}

The train of thought of a Euro-Western jurisprudence can be broken down into three main parts: (1) Modern Europe is seen as the centre of civilisation worldwide, (2) this creates a sense of superiority which depicts anyone or anything that is outside the scope of Modern Europe

32 G Budlender 'Transforming the judiciary: The politics of the judiciary in a democratic South Africa' (2005) 4 South African Journal on Human Rights 449.

33 Statistics South Africa http://www.statssa.gov.za/census/census_2011/census products/Census_2011_Census_in_brief.pdf. (accessed 20 May 2020).

34 Commission for Gender Equality 'Lack of gender transformation in the judiciary investigative report' 2016.

35 M Sedutla 'Necessary Transformation' (2013) 532 De Rebus 10-13. 
as inferior and in need of 'development' to become civilised. (3) this process of civilising non-Western, non-European places and beings is to be dictated and completed according to the standards compiled by the Modern Western European Man - specifically referred to as 'the Man', because of the tendency of the Western/Europe world to regard women as almost child-like, weaker and thus as lesser beings. ${ }^{36}$

This kind of thought has created a narrative in legal education where those falling outside the scope of the European Man is seen as not deserving of legal education, ending any control over the society in which these individuals have. With the violent conquest and dispossession of land that came with colonialism which later bore imperialism, the process of Western education was introduced to Africans as a means to create a docile class of willing transmitters of the colonial culture. ${ }^{37}$ Fortunately, this was not successful as lawyers such as Alfred Mangena and Pixley ka Isaka Seme would use that same Western education as tools to fight against the system. These two are, however, just the exception to how things generally panned out for black people.

Most of the first black South African lawyers studied in colleges abroad. Tiyo Soga, who was possibly the first black South African who to obtain formal education aboard around 1865 is an example of such a lawyer. ${ }^{38}$ He later got married to a Scottish woman and had children whom he wished to be educated in Glasgow as he contended that there was no adequate education for non-white children. Formal education in the form of the first established school in the country began in 1658 , founded by a man who has essentially became the 'face' of the Dutch East India Company, Jan van Riebeeck. The school catered to slave children and was incredibly oppressive as the children would be forced to abandon their original identities and assimilate. ${ }^{39}$ They received very harsh treatment from the colonial powers and in exchange for obedience, would essentially be bribed with alcohol. ${ }^{40}$ Later on, the British colonialists created a department for education in the Cape. The department was established to further the interests of building a white, British empire in collaboration with the Anglican Church.

The Mineral Revolution came with many wars, including identity and cultural elements of war. Conquest over the Nguni and Sesotho

36 SA Burrell Handbook of Western Civilisation 1700 to Present $2^{\text {nd }}$ Edition (1965) 67.

37 T Ngcukaitobi The land is ours: South Africa's first black lawyers and the birth of constitutionalism (2018) 328.

38 D Killingray 'Significant Black South Africans in Britain before 1912: Pan-African Organisation and the Emergence of South Africa's First Black Lawyers' (2012) 64 South African Historical Journal 394.

39 South African History Online 'Amersfoort legacy - history of education in South Africa' 27 August 2019 https://www.sahistory.org.za/article/amersfoort-legacyhistory-education-south-africa (accessed 21 May 2020).

40 South African History Online (n 39 above). 
nations had set in, with the help of missionaries who imposed the British way of life all over the country. ${ }^{41}$ An obsession over the newly found gold and diamonds took attention away from the schooling of the people and as the economy grew, a need for a great deal of manual (forced) labour also emerged. This would form the basis of education for black children for many years later, making it extremely difficult for non-white children to pursue occupations other than those in agriculture, metalwork and other industrial and menial work (skills that would build the British colonial economy). ${ }^{42}$ In this respect, it is understandable why many Africans and other black people who were presented with the opportunity, by the British to its Imperial subjects, to legally own property, live where they wanted to and work in whichever professions they chose to tried by all means to study overseas and gain as much knowledge as they could. ${ }^{43}$

In 1948, the National Party won the election and legalised racism for the next four decades. Every aspect of life; social, political, economic was governed by race. The white race was subsequently placed at the top of this racial hierarchy, and every other race was viewed as and treated as inferior. In the early 1950s, the Bantu Education Act came into force with two aims: to facilitate the end of missionary education of black people and the advancing of mass education geared towards preparing the African children for roles of servitude. ${ }^{44}$ There was never anything beyond that and despite the legal profession's role as the cornerstone in addressing this system of legalised/institutional racism and the domain of white men, it was also hardly addressed. The rare appearances of the likes of Oliver Tambo and Nelson Mandela who became lawyers and had their own law firm at one point, only speaks to the sheer resilience of black people even under the most unbearable conditions.

Modern Western European thought continued to echo through the development and use of the common law which is a manifestation of Christian culture, composing of the historic belief that God placed women deliberately in a subordinate position to men. ${ }^{45}$ In light of the impact of colonialism, imperialism, and then later apartheid, law and legal education gave an overall message that said 'Non-white persons and women are not welcome to participate in law but are bound by it'. The accompanying Christian thought makes for a double punishment for black women lawyers and black women in general. Black women lawyers are then the target of discrimination on the basis of skin colour/race plus gender and are thus in a far more vulnerable position in the profession than anyone else and would

41 South African History Online (n 39 above).

42 Ngcukaitobi (n 37 above) 18-19.

43 Killingray (n 38 above) 395.

44 Bantu Education Act 47 of 1953.

45 GJ Watkins Feminism Is for Everybody (2000) 2. 
require far more attention to bring them to an equal position with white lawyers.

\section{What changes have occurred for black women lawyers in South African since 1994?}

Transformation and more specifically, measures like affirmative action, does not advocate for the appointment of a less qualified person in whatever position simply to fill a quota or simply because that person belongs to the category of previously disadvantaged persons. Transformation rather serves to remove the unreasonable barriers put in place by colonialism and apartheid. The aim is to stop impediments faced by certain lawyers so as to ensure that they are offered opportunities to develop and gain skills and experience. It also requires asking difficult and uncomfortable questions.

To be able to affect any sort of change, one would have to look at what conditions are required for the change or transformation to commence. This action - of looking at what the conditions required for transformation is part of the main premise of transformative constitutionalism. ${ }^{46}$

For black women, these conditions will have to speak to their underrepresentation in the workplace, specifically in the legal profession. In order to understand the root of this inequality and continuance of systems purporting this inequality, one needs to understand 'where power comes and collides, where it interlocks..." 47 The term, 'intersectionality' was coined by one of the leading scholars on Critical Race Theory and Colombia Law School professor, Kimberlé Crenshaw, who introduced this concept as a way to help express the particular oppression of African-American women; the bias and violence they face and the dismissal of their cases when they approached as victims of discrimination on the basis of race and gender. The professor introduced the term to explain the multidimensions of the particular manner in which black women are subordinated. 48

The position of black women in society is unique because of its compounded nature. There is their 'blackness', which qualifies them as members in the various liberation efforts which black people have made throughout South African history, and then there is their 'femaleness' which qualifies them as part of the feminist efforts. The issue is that both movements only speak to one side of black women;

46 Klare (n 4 above) 352.

47 Colombia Law School 'Kimberlé Crenshaw on intersectionality, more than two decades later' https://www.law.columbia.edu/pt-br/news/2017/06/kimberlecrenshaw-intersectionality (accessed 15 May 2019). 
they place black women in a 'one must die' situation where black women are in a constant limbo between two struggles. This leads to a situation where black woman have to choose between fighting for women's rights and against patriarchy or fighting against racism and its many manifestations. ${ }^{49}$

\section{Some of the efforts made by (black) women in addressing inequality}

Considering the how women were involved in and gradually ended up leading the movement for democracy and how the Constitution was in part constructed by (black) women, it can be said that this on its own is a step in the right direction. ${ }^{50}$ The Constitution (including the Interim Constitution) is one of the most prominent signs of transformation; it was a matter of using the law to change an oppressive law. ${ }^{51}$ The Constitution introduced a vision of an egalitarian society and demanded a nationwide process of transformative constitutionalism. ${ }^{52}$ The Constitution expressly places a duty on the judiciary to 'reflect broadly the racial and gender composition of South Africa' among other obligations. ${ }^{53}$ The Johannesburg Bar and the Cape Town Bar as well as the Legal Resources Centre collaborated and have recently introduced the Annual Chaskalson Pupillage Fellowship in 2016 which is aimed at black aspiring advocates, especially black women aspiring advocates. ${ }^{54}$ This is signals the awareness of the compounded nature of the black women's experience in the country. This awareness intersectionality of being a black female in a country with centuries of oppression, particularly through the use of law, only advances and supports racism and thus hinders one's pursuit in aspiring towards a legal career as a black female.

Other means of transformation include the implementation affirmative action aimed at giving opportunities and socio-economic empowerment and access to the previously disadvantaged. ${ }^{55}$ It is certainly positive to see the rise in women pursuing legal education and law degrees now that traditionally Afrikaans universities are also now available to educate anyone.

49 Colombia Law School (n 47 above).

50 Phooko (n 20 above) 326.

51 Constitution of the Republic of South Africa, Act 200 of 1993 ('Interim Constitution').

52 Klare (n 3 above) 150.

53 Constitution of the Republic of South Africa, 1996 sec 174(1-4).

54 D Chambers Time Live 1 'Lawyers ready to foot R100 000 bar bill in transformation drive' September 2016 http://www.timeslive.co.za/local/2016/ 09/01/Lawyers-ready-to-foot-R100\%E2\%80\%9A000-Bar-bill-in-transformationdrive?platform=hootsuite (accessed 16 May 2020).

55 Klare (n 3 above) 152. 


\section{The South African legal culture and where black people fit within it}

The South African legal culture is one that has been built to be in favour of white male lawyers. Karl Klare defines a legal culture as the 'professional sensibilities, understandings and assumptions' relating to politics, social life and justice which are deemed part of the legal field. ${ }^{56}$ Klare asserts that those within a legal culture are often unaware that this culture can have the effect of dictating their ideas as well as the responses to various legal issues (i.e. 'skiing with the right people'). ${ }^{57}$ This, in turn, has influence on the development of law in a substantive way.

The South African lawyer is a stickler for conservative analysis, according to Klare. There is an intense habit of being overly-cautious when dealing with law and the tendency to treat law as infinitely sacred. This is not to say we should not respect the law or be dismissive of it, however a change in perspective could prove useful - the law is meant to serve human life and should accommodate human life, not the other way around. It is not the cure to all societal problems but is frequently the first avenue for transformation projects and understandably so; many times it was the law that enforced and reinforced segregation, sexism and other forms of oppression, and so it would be reasonable to use law to try to undo that damage. ${ }^{58}$

The introduction of the Legal Practice Act and the changed patterns of the State Attorney's Office and other government offices where the briefing of black advocates is especially common, has also brought in change to the profession. ${ }^{59}$ The Legal Practice Act provides that membership of legal institutions such as the South African Legal Practice and the Provincial Councils must reflect the gender and racial make-up of the country.

The overall aim of any attempt to achieve transformation is based on inclusion and this is seen from documents such as the current Constitution, to various statutes and racial and gender criteria set for the appointment of black lawyers and judges. This is a noble and meaningful approach, but it will be ineffective and problematic if this inclusion is implemented in an unchanged environment which still possess the structures and traits of oppression and substantive inequality. Not enough change can be implemented in the profession 
if the 'enduring residue of the colonial past' is not addressed systematically. ${ }^{60}$

It is argued by Beth Goldblatt and Catherine Albertyn that the Constitution aimed at substantive equality in order to address the social and economic inequalities experienced in the ordinary lives of South Africans. ${ }^{61}$ Albertyn asserts that equality goes beyond just inclusion and involves changing the social structures, norms and attitudes which have reproduced inequality since the days of cocolonisation. She states that this is different from the egalitarian approach in that there is less focus on individuals and more focus on the conditions that cause, support and shield inequality. ${ }^{62}$

\section{Glimmers of hope}

Considering where we come from as a country, what the political agendas of the apartheid government brought about, as well as the extreme impediments and regression in various forms black people and for non-white people in general, it is certainly remarkable to see increasing statistics of black students enrolling at law schools, graduating and completing their articles. If nothing else, this is at dent in the work which still needs to be done on the journey to substantive equality in the legal field. At this time, perhaps it is hopeful enough to see a 'representation' of the community of black women lawyers sitting at the proverbial table where there previously was none.

\section{Conclusion}

Implementing social inclusion into existing systems in their current conditions will not be enough to establish a substantively equal institution or society. It is enough to get the ball rolling, but that is not where transformation should end; in fact, one could say that the transformation process should never actually end, but should rather be a continuous process where we investigate and evaluate the legal profession and other spheres of societal life in South Africa and ensure that the systems are in line with the values we wish to uphold in the society: Freedom, Dignity, Ubuntu and Equality.

60 T Serequeberhan 'African philosophy as the practice of resistance' (2009) 4 Journal of Philosophy: A Cross-disciplinary Inquiry 44.

61 Albertyn (n 8 above) 248-249.

62 C Albertyn 'Contested substantive equality in the South African Constitution: Beyond social inclusion towards systemic injustice' (2018) 34 South African Journal of Human Rights 461-462. 